\title{
Summary of recommendations for the prevention of viral hepatitis during travel
}

\author{
Committee to Advise on Tropical Medicine and Travel (CATMAT)*
}

* Corresponding author: catmat.secretariat@phac-aspc.gc.ca

\section{Abstract}

Viral hepatitis is considered the most common travel-related, vaccine-preventable disease. All non-immune travellers to developing countries should consider vaccination with inactivated Hepatitis $A(H A)$ virus vaccine and recombinant Hepatitis $B(H B)$ virus vaccine. Inactivated $H A$ and recombinant $H B$ vaccines are safe, have few side effects and are effective in providing long-lasting protection. All monovalent HA and HB vaccines available for use within Canada are equally effective, and each can be used interchangeably. HA Ig (immune globulin) should be used to prevent HA only in those for whom active HA vaccines are contraindicated, in immunocompromised individuals who may not respond adequately to the active vaccines or in infants less than one year of age. All travellers should practise routine protective measures when abroad. HB virus carriers travelling to Hepatitis D virus-endemic countries should be particularly vigilant in avoiding high-risk activities such as skin piercing and unsafe sexual practices.

\section{Background}

Hepatitis $A$ is the most common travel-related illness for which there is an effective vaccine. A map of countries and areas of risk for Hepatitis A (HA) virus and Hepatitis B (HB) virus is available from the World Health Organization. Detailed information about HA and HB, including the epidemiology in Canada, available vaccines, recommendations for use in Canada and precautions and contraindications can be found in the Canadian Immunization Guide. A full summary of the background of risks of HA and HB among travellers and recommendations are available in the Committee to Advise on Tropical Medicine (CATMAT)'s statement on hepatitis vaccines for travellers (1).

\section{Prevention}

\section{Vaccine recommendations for Canadian travellers}

Inactivated $\mathrm{HA}$ and recombinant $\mathrm{HB}$ vaccines are safe, have few side effects, and are effective in providing longlasting protection $(2,3)$. Both are considered safe in pregnancy and lactation (3,4). All monovalent $\mathrm{HA}$ and $\mathrm{HB}$ vaccines available for use within Canada are equally effective and each can be used interchangeably against its respective target virus $(3,5)$.

All non-immune travellers to developing countries should consider vaccination with inactivated $\mathrm{HA}$ and recombinant $\mathrm{HB}$ vaccine (2,6-9).

Administration of HA vaccine up to the day of departure is considered efficacious and need not be accompanied by immune globulin (lg) administration $(10,11)$.

For travellers who have no or an incomplete history of $\mathrm{HB}$ vaccination, completion of a vaccination series is recommended before departure. One or two doses of $\mathrm{HB}$ vaccine administered before travel will still provide some protection and may initiate an HB vaccination series that can be completed after travel for those who cannot complete the full series before departure (1). 
For travellers presenting less than 21 days before departure, monovalent $\mathrm{HA}$ and $\mathrm{HB}$ vaccines should be administered separately, with completion of both immunization series after travel (1).

Travellers already infected with Hepatitis $\mathrm{C}$ should receive HA and HB vaccines, if not already administered by their primary care provider (1).

$\mathrm{HA}, \mathrm{HB}$ and $\mathrm{HAHB}$ vaccines may be administered concomitantly with other vaccines at different injection sites using separate needles and syringes (3).

\section{Immune globulin}

Vaccine is the preferred agent for pre-exposure prophylaxis for HA, therefore Ig should be used to prevent HA only in those for whom active HA vaccines are contraindicated, in immunocompromised individuals who may not respond adequately to the active vaccines or in infants under one year of age $(1,3)$.

Co-administration of Ig and HA vaccine is not necessary (except possibly in immunocompromised individuals) and may result in an attenuated immune response to the HA vaccine $(10,12,13)$.

There are no immunoglobulin preparations or effective vaccines available in Canada that provide protection against Hepatitis C, D or E virus (9,14-18).

For individuals with a high likelihood of prior exposure (e.g. long-term residence in a highly endemic region or history of a compatible illness) and for whom cost is a significant issue, it may be reasonable to assume immunity. It may be cost-effective to test adults who grew up in developing countries or Canadian-born adults born before 1945 for anti-HA IgG prior to travel, if time permits, and immunize only those susceptible $(3,19,20)$.

\section{Routine serology}

Routine serologic testing after HA or HB vaccination is unnecessary except for HB among health care workers and immunocompromised travellers, who should confirm their seroprotection $(3,21,22)$. Refer to the Canadian Immunization Guide for additional risk groups recommended to have pre-immunization serologic testing for $\mathrm{HB}$.

Routine serologic testing of previously immunized travellers for anti-HBs (antibody to Hepatitis B surface antigen) $\lg \mathrm{G}$ is not necessary unless they are health care workers who have never had their anti-HBs titres verified (3).

\section{Personal protective measures}

Travellers should be advised to do the following:

- Closely follow food and water precautions and wash their hands frequently to minimize the possibility of exposure to HA or Hepatitis E (23-25).

- Adopt safer sexual practices and avoid any voluntary skin piercing, such as tattooing, acupuncture and body piercings, to minimize the possibility of exposure to HB, Hepatitis $C$ or Hepatitis $D$.

- Take great care when seeking medical or dental care requiring percutaneous or invasive procedures, to minimize the possibility of exposure to $\mathrm{HB}$, Hepatitis $\mathrm{C}$ or Hepatitis $\mathrm{D}(1,21)$.

HB carriers travelling to Hepatitis D-endemic countries should be particularly vigilant in avoiding high-risk activities such as skin piercing and unsafe sexual practices (1).

Human immunoglobulin does not provide protection against Hepatitis C, Hepatitis D or Hepatitis E, and currently no vaccines targeting these infections are available. 


\section{References}

(1) Committee to Advise on Tropical Medicine and Travel. Statement on Hepatitis Vaccines for Travellers. Can Commun Dis Rep 2008;34(ACS-2):1-24.

(2) Keystone JS. Travel-related hepatitis B: Risk factors and prevention using an accelerated vaccination schedule. Am J Med 2005;118(10):63-68.

(3) Public Health Agency of Canada. Canadian Immunization Guide. 2014. http://www.phac-aspc.gc.ca/publicat/cig-gci/. Accessed 5/29/2014.

(4) Duff B, Duff P. Hepatitis A vaccine: Ready for prime time. Obstet Gynecol 1998;91(3):468-471.

(5) Zuckerman JN, Kirkpatrick CT, Huang M. Immunogenicity and reactogenicity of Avaxim (160 AU) as compared with Havrix (1440 EL.U) as a booster following primary immunization with Havrix (1440 EL.U) against hepatitis A. J Travel Med 1998 Mar;5(1):18-22.

(6) Zuckerman JN, Steffen R. Risks of hepatitis B in travelers as compared to immunization status. J Travel Med 2000;7(4):170-174.

(7) Mutsch M, Spicher VM, Gut C, Steffen R. Hepatitis A virus infections in travelers, 1988-2004. Clin Infect Dis 2006 Feb 15;42(4):490-497.

(8) Van Damme P, Van Herck K. Effect of hepatitis A vaccination programs. JAMA 2005 Jul $13 ; 294(2): 246-248$

(9) Centers for Disease Control and Prevention. CDC Health Information for International Travel 2014. New York: Oxford University Press; 2014.

(10) Connor BA. Hepatitis A vaccine in the last-minute traveler. Am J Med 2005 Oct;118:58-62.

(11) Sagliocca L, Amoroso P, Stroffolini T, Adamo B, Tosti ME, Lettieri G, et al. Efficacy of hepatitis A vaccine in prevention of secondary hepatitis A infection: A randomised trial. Lancet $1999 \mathrm{Apr}$ 3;353(9159):1136-1139.

(12) Werzberger A, Mensch B, Kuter B, Brown L, Lewis J, Sitrin R, et al. A controlled trial of a formalininactivated hepatitis A vaccine in healthy children. N Engl J Med 1992 Aug 13;327(7):453-457.

(13) Bader TF. Hepatitis A vaccine. Am J Gastroenterol 1996 Feb;91(2):217-222.

(14) Heymann DL. Viral Hepatitis C. In: Control of Communicable Disease Manual. 19th ed. Washington, DC: American Public Health Association; 2008. p. 293-295.

(15) Heymann DL. Viral Hepatitis E. In: Control of Communicable Diseases Manual. 19th ed. Washington, DC: American Public Health Association; 2008. p. 298-300.

(16) Khuroo MS. Viral hepatitis in international travellers: Risks and prevention. Int J Antimicrob Agents 2003 Feb;21(2):143-152.

(17) Puro V, De Carli G, Scognamiglio P, Porcasi R, Ippolito G, Studio Italiano Rischio Occupazionale HIV. Risk of HIV and other blood-borne infections in the cardiac setting: Patient-to-provider and provider-to-patient transmission. Ann N Y Acad Sci 2001 Nov;946:291-309.

(18) Heymann DL. Delta Hepatitis. In: Control of Communicable Diseases Manual. 19th ed. Washington, DC: American Public Health Association; 2008. p. 295-297.

(19) Grabenstein J. Hepatitis A vaccine. ImmunoFacts 2006:175-85. 
(20) Ford PM, White C, Kaufmann H, MacTavish J, Pearson M, Ford S, et al. Seroprevalence of hepatitis $C$ in a Canadian federal penitentiary for women. Can Commun Dis Rep 1995;21(14):132-134.

(21) Hutin YJ, Hauri AM, Armstrong GL. Use of injections in healthcare settings worldwide, 2000: Literature review and regional estimates. BMJ 2003 Nov 8;327:1075-80.

(22) Pasricha N, Datta U, Chawla Y, Singh S, Arora SK, Sud A, et al. Poor responses to recombinant HBV vaccination in patients with HIV infection. Trop Gastroenterol 2005 Oct-Dec;26(4):178-182.

(23) Committee to Advise on Tropical Medicine and Travel. Statement on travellers' diarrhea. Can Commun Dis Rep 2001;27:1-12.

(24) World Health Organization. Hepatitis A. 2013. http://www.who.int/mediacentre/factsheets/fs328/en/. Accessed 5/28/2014.

(25) World Health Organization. Hepatitis E. 2013. http://www.who.int/mediacentre/factsheets/fs280/en/. Accessed 5/28/2014.

\section{Acknowledgements}

This summary was prepared and reviewed by Teitelbaum P, Libman M, Crockett M, McCarthy A and Geduld J (Public Health Agency of Canada).

CATMAT members: Boggild A, Brophy J, Bui YG, Crockett M, Ghesquiere W, Greenaway C, Henteleff A, Libman $M$, Teitelbaum $P$ and McCarthy A (Chair).

Liaison members: Hui C (Canadian Paediatric Society) and Gershman M (US Centers for Disease Control and Prevention).

Ex-officio members: Marion D (Canadian Forces Health Services Centre, Department of National Defence), McDonald P (Division of Anti-Infective Drugs, Health Canada), Schofield S (Directorate of Force Health Protection, Department of National Defence) and Tepper M (Directorate of Force Health Protection, Department of National Defence).

Member Emeritus: Jeanes CWL.

\section{Conflict of interest}

None declared. 